\title{
The vectorial transport of salts and water is crucial for respiratory epithelial cell lines
}

\author{
Khaled Khoufache
}

\begin{abstract}
Primary culture of respiratory epithelial cells is useful to study the pathophysiology of respiratory diseases. However, such primary culture has been very limited because of its high dependence on the availability of biopsies and the long time required to reach confluence. Therefore, cell lines are an alternative to primary cultures because they reach confluence faster and some can maintain their differentiation abilities. However, unlike primary cultures and native tissues just some cell lines are able to polarize, with normal channel functionality and transepithelial ionic flux.
\end{abstract}

Keywords: Airway epithelial model, Mucociliary differentiation, Polarization, Trans epithelial resistance, Trans epithelial ionic flux

\section{Dear Editor}

I read with great enthusiasm the recent article written by Matthew Walters and colleagues in BMC Respiratory Research [1]. The authors reported the establishment of a basal cell line, BCi NS1.1, from respiratory epithelial basal cells of healthy non-smokers. The original cells were immortalized using a recombinant virus carrying the human telomerase gene. The established cell line maintained the properties of the original cells 30 even after 40 passages. Moreover, a mucociliary phenotype (positivity for MUC5AC, MUC5B, TFF3, CC10, DNAI1, and FoxJ1) was obtained by culture at the liquid air-interface. In addition, confluence of the cultures was confirmed by trans epithelial resistance (Rte) $\left(57 \pm 4 \Omega \times \mathrm{cm}^{2}\right.$ at day 10 , $165 \pm 67 \Omega \times \mathrm{cm}^{2}$ at day $14,1312 \pm 281 \Omega \times \mathrm{cm}^{2}$ at day 28 , and $1563 \pm 86 \Omega \times \mathrm{cm}^{2}$ at day 40 ). Therefore, the authors concluded that the BCi NS1.1 cell line accurately mimics the airway epithelium, and can be considered as a model to study the interactions with environmental stimuli, cytokines, cigarette smoke or as a target for assessing of pharmacologic agents. However, studies of such interactions with the environment or drugs require not only a $100 \%$ confluent culture but also polarization. The authors examined the Rte but this parameter is not sufficient to make conclusions about the polarization status of the cell line. Additionally, the

Correspondence: khaled.khoufache.1@ulaval.ca

Research Center, Saint-François d'Assise Hospital, Centre Hospitalier Universitaire de Québec (CHUQ), Québec City, QC, Canada
Rte was $57 \pm 4 \Omega \times \mathrm{cm}^{2}$ (day 10) and $165 \pm 67 \Omega \times \mathrm{cm}^{2}$ (day 14) [2-5]. Moreover, this cell line requires more than 20 days to obtain Rte, which is comparable to the native epithelium [5]. Furthermore, confluence and the differentiation capacity of the monolayer do not necessarily indicate functionality, because a biological process called trans epithelial vectorial transport of salts and water must be present. In fact, normal flux transport indicates normal expression and functions of membrane-bound ion channels such as $\mathrm{NaCl}-, \mathrm{K}+$, and $\mathrm{Na}+$ and the cystic fibrosis transmembrane conductance regulator (CFTR) [4, 6-9]. Each of these channels is crucial because dysfunction of one can cause severe pathologies [10]. A mutation in CFTR causes cystic fibrosis, suggesting the importance of this channel protein [11]. However, it has been documented that CFTR is not expressed in human airway basal cells [12]. Moreover, a previous study has shown that primary cystic fibrosis cell culture and some cystic fibrosis cell lines, secretes $\mathrm{Cl}$ in response to agonists [13]. That why it is important to analyze the transepithelial ionic flux. For this purpose, two parameters can be measured: (i) the potential difference $(\mathrm{mV})$ and (ii) the short circuit current (Isc) $\left(\mu \mathrm{A} / \mathrm{cm}^{2}\right)$. Similar to native epithelium, passage 2 and 3 tracheobronchial epithelial cell cultures show Rte $\left(500-800 \Omega \times \mathrm{cm}^{2}\right)$, but the equivalent Isc is much lower than that in native tissue $(3 \mu \mathrm{A} / \mathrm{cm} 2)[5,14]$. Furthermore, the Rte and Isc decrease to $100 \Omega \times \mathrm{cm}^{2}$ and $2 \mu \mathrm{A} / \mathrm{cm}$, respectively, at passage 4 . In another study, human airway epithelial cells were successfully 
passaged up to six times with an Rte of 1000-4000 $\Omega \times \mathrm{cm}^{2}$ and Isc of $5 \mu \mathrm{A} / \mathrm{cm}$ [15]. Moreover, the results indicated few ciliated cells (only $10 \%$ ), whereas ciliated cells comprise 60-90\% of the surface of normal respiratory epithelium. In addition to maintaining barrier integrity, ciliated cells are important for absorption and secretion of electrolytes, which generate potential difference $[16,17]$. Therefore, I believe that differentiation and cell polarization are inseparable parameters. Consequently, checking the new cell line for its vectorial transport of salts and water would be a useful addition.

\section{Abbreviations}

BCi NS1.1: Clone basal cell immortalized-nonsmoker 1; KRT5: Keratin 5; TP63: Tumor protein p63; TFF3: Trefoil factor 3; MUC5AC: Mucin 5, subtypes A and C; MUC5B: Mucin 5, subtype B; CC10: Clara cell protein 10; DNAl1: Dynein, axonemal, intermediate chain 1; FoxJ1: Forkhead box J1

\section{Competing interests}

The author declares that he has no competing interests.

\section{Acknowledgements}

I would like to give my sincere gratitude to Prof. Stéphane Bretagne (Groupe Hospitalier Saint-Louis-Lariboisière-Fernand-Widal, Paris, France and Université Paris-Diderot, Sorbonne Cité, Paris, France) and Dr. Nadège Michaud (Research Center, Saint-François d'Assise Hospital, Centre Hospitalier Universitaire de Québec (CHUQ), Québec City, Québec, Canada) for reading the manuscript and providing their comments.

Received: 18 December 2014 Accepted: 10 June 2015

Published online: 12 June 2015

\section{References}

1. Walters MS, Gomi K, Ashbridge B, Moore MA, Arbelaez V, Heldrich J, et al. Generation of a human airway epithelium derived basal cell line with multipotent differentiation capacity. Respir Res. 2013;14:135.

2. Khoufache $K$, Cabaret $O$, Farrugia C, Rivollet D, Alliot A, Allaire E, et al. Primary in vitro culture of porcine tracheal epithelial cells in an air-liquid interface as a model to study airway epithelium and Aspergillus fumigatus interactions. Med Mycol. 2010;48(8):1049-55.

3. Saha P, Kim KJ, Lee VH. A primary culture model of rabbit conjunctival epithelial cells exhibiting tight barrier properties. Curr Eye Res. 1996;15(12):1163-69.

4. Liu X, Luo M, Zhang L, Ding W, Yan Z, Engelhardt JF. Bioelectric properties of chloride channels in human, pig, ferret, and mouse airway epithelia. Am J Respir Cell Mol Biol. 2007;36(3):313-23.

5. Widdicombe $J H$, Sachs LA, Morrow $J$, Finkbeiner WE. Expansion of cultures of human tracheal epithelium with maintenance of differentiated structure and function. Biotechniques. 2005;39(2):249-55.

6. Botterel F, Cordonnier C, Barbier V, Wingerstmann L, Liance M, Coste A, et al. Aspergillus fumigatus causes in vitro electrophysiological and morphological modifications in human nasal epithelial cells. Histol Histopathol. 2002;17(4):1095-101.

7. Kunzelmann K, Kathofer S, Hipper A, Gruenert DC, Gregner R. Culture-dependent expression of $\mathrm{Na}+$ conductances in airway epithelial cells. Pflugers Arch. 1996;431:578-86.

8. Linsdell P. Functional architecture of the CFTR chloride channel. Mol Membr Biol. 2014;31(1):1-16.

9. Kunzelmann K, Kathofer S, Greger R. Na + and Cl- conductances in airway epithelial cells: increased $\mathrm{Na}+$ conductance in cystic fibrosis. Pflugers Arch. 1995;431(1):1-9.

10. Ferec C, Cutting GR. Assessing the Disease-Liability of Mutations in CFTR. Cold Spring Harb Perspect Med. 2012;2(12):a009480.

11. Song $Y$, Lou HH, Boyer JL, Limberis MP, Vandenberghe LH, Hackett NR, et al. Functional cystic fibrosis transmembrane conductance regulator expression in cystic fibrosis airway epithelial cells by AAV6.2-mediated segmental trans-splicing. Hum Gene Ther. 2009;20(3):267-81.
12. Hackett NR, Shaykhiev R, Walters MS, Wang R, Zwick RK, Ferris B, et al. The human airway epithelial basal cell transcriptome. PLoS One. 2011;6(5):e18378.

13. Jefferson DM, Valentich JD, Marini FC, Grubman SA, lannuzzi MC, Dorkin HL, et al. Expression of normal and cystic fibrosis phenotypes by continuous airway epithelial cell lines. Am J Physiol. 1990;259(6 Pt 1):L496-505.

14. Gray TE, Guzman K, Davis CW, Abdullah LH, Nettesheim P. Mucociliary differentiation of serially passaged normal human tracheobronchial epithelial cells. Am J Respir Cell Mol Biol. 1996;14(1):104-12.

15. Galietta LJ, Lantero S, Gazzolo A, Sacco O, Romano L, Rossi GA, et al. An improved method to obtain highly differentiated monolayers of human bronchial epithelial cells. In Vitro Cell Dev Biol Anim. 1998;34(6):478-81.

16. Chapelin C, Coste A, Gilain L, Poron F, Verra F, Escudier E. Modified epithelial cell 132 distribution in chronic airways inflammation. Eur Respir J. 1996;9:2474-8.

17. Jeffery PK, Brain AP. Surface morphology of human airway mucosa: normal, carcinoma or cystic fibrosis. Scanning Microsc. 1988;2:553-60.

\section{Submit your next manuscript to BioMed Central and take full advantage of:}

- Convenient online submission

- Thorough peer review

- No space constraints or color figure charges

- Immediate publication on acceptance

- Inclusion in PubMed, CAS, Scopus and Google Scholar

- Research which is freely available for redistribution 